\title{
Uji Aktivitas Bakteri Keratinolitik Sebagai Penghasil Biosurfaktan
}

\section{(Assay of Keratinolytic Bacterial Activity to Producing Biosurfactant)}

\author{
Yayuk Putri Rahayu ${ }^{*}$, Healthy Aldriany Prasetyo
}

1*Program Studi Farmasi, Fakultas Farmasi, Universitas Muslim Nusantara Al-Washliyah, Jalan Garu II No. 93, Medan, 20147, Sumatera Utara, Indonesia

${ }^{2}$ Program Studi Teknik Industri, Fakultas Teknik, Universitas Quality, Jl. Ngumban Surbakti No.18, Medan, 20132, Sumatera Utara, Indonesia

Email: yayukputri@umnaw.ac.id

\author{
Article Info: \\ Received: 21 June 2020 \\ Accepted: 27 August \\ 2020 \\ DOI: \\ 10.33772/pharmauho. \\ v6i2.12533
}

\begin{abstract}
The use of surfactants in various industries can cause problems in their use because it can cause environmental pollution because it is difficult to decompose (nonbiodegradable). Based on this, it is necessary to find sources of surfactants that are safe for the environment such as biosurfactants derived from microorganisms, one of which is keratinolytic bacteria. The purpose of this study was to find biosurfactant-producing sources of keratinolytic bacterial isolates using oil displacement and emulsification techniques. Biosurfactant activity testing techniques with the oil displacement method
\end{abstract} were carried out to measure the oil transfer zone to obtain the value of the oil displacement area (ODA), and the emulsification method was carried out to determine the emulsification index value (IE24). The results of biosurfactant activity assay in each isolate of keratinolytic bacteria obtained a maximum ODA of 38.0 and 15.0 mm and EI24 of 20 and $15 \%$. The biosurfactant activity obtained in the oil displacement test is in line with the results obtained in the emulsification test. The results of this study it can be concluded that keratinolytic bacteria are able to produce biosurfactants even though their value is small

Keywords: biosurfactants, emulsification index, keratinolytic bacteria, oil displacement

\begin{abstract}
Abstrak
Penggunaan surfaktan dalam berbagai industri dapat menjadi masalah karena dapat menyebabkan pencemaran lingkungan karena sifatnya yang sulit terurai (non biodegradable). Berdasarkan hal tersebut perlu mencari sumber surfaktan yang aman bagi lingkungan seperti biosurfaktan yang berasal dari mikroorganisme, salah satunya bakteri keratinolitik. Tujuan penelitian ini adalah untuk mencari sumber penghasil biosurfaktan dari isolat bakteri keratinolitik menggunakan teknik metode oil displacement dan emulsifikasi. Teknik pengujian aktivitas biosurfaktan dengan metode oil displacement dilakukan untuk mengukur zona perpindahan minyak untuk mendapatkan nilai oil displacement area (ODA), dan metode emulsifikasi dilakukan untuk menentukan nilai indeks emulsifikasi (IE24). Hasil pengujian aktivitas biosurfaktan pada masing-masing isolat bakteri keratinolitik diperoleh nilai maksimal ODA sebesar 38.0 dan $15.0 \mathrm{~mm}$ dan EI24 sebesar 20 dan 15\%. Peningkatan nilai yang diperoleh pada pengujian oil displacement relatif sejalan dengan meningkatnya nilai yang diperoleh pada pengujian emulsifikasi. Dari hasil penelitian ini dapat disimpulkan bahwa bakteri keratinolitik mampu menghasilkan biosurfaktan meskipun nilainya kecil.
\end{abstract}

Kata kunci: bakteri keratinolitik, biosurfaktan, indeks emulsifikasi, oil displacement 


\section{Pendahuluan}

Penggunaan surfaktan dalam berbagai industri dapat menyebabkan masalah dalam penggunaannya. Hal ini dikarenakan surfaktan dapat menyebabkan pencemaran lingkungan karena sifatnya yang sulit terurai atau bersifat non biodegradable. Sifat surfaktan yang sulit terurai menyebabkan perlunya mencari sumber surfaktan yang aman bagi lingkungan seperti biosurfaktan. Biosurfaktan adalah senyawa aktif permukaan yang dapat disintesis oleh mikroba, yang sifatnya mampu mereduksi (menurunkan) tegangan permukaan cairan, namun mudah terurai atau bersifat biodegradable sehingga ramah bagi lingkungan. Salah satu manfaat biosurfaktan yaitu dapat digunakan sebagai pengemulsi agar hidrokarbon dapat larut dalam air sehingga dapat digunakan dalam berbagai industri seperti industri farmasi, obat-obatan, kosmetik, makanan, deterjen, formulasi herbisida dan pestisida [1].

Biosurfaktan dapat berasal dari mikroba seperti bakteri [2]. Beberapa penelitian sebelumnya menyebutkan bahwa mikroorganisme yang dapat memproduksi biosurfaktan diantaranya: Bacillus subtillis A1 yang menghasilkan biosurfaktan sebagai pendegradasi pencemaran minyak mentah yang mencemari lingkungan [3], Achromobacter sp., Serratia sp., Sphingomonas sp. dan Micrococcus sp. menghasilkan biosurfaktan yang dapat digunakan untuk Enhanced Oil Recovery (EOR) dalam meningkatkan perolehan minyak mentah [4] . Aplikasi biosurfaktan juga dapat digunakan dalam bidang farmasi atau obat-obatan, berbagai industri perawatan tubuh, dan agen biologis. Hasil penelitian menyebutkan bahwa Pseudomonas aeruginosa ATCC-10145 menghasilkan biosurfaktan rhamnolipid yang memiliki aktivitas antimikroba terhadap berbagai spesies bakteri dan jamur sehingga dapat diterapkan sebagai obat-obatan atau agen biokontrol [5]. Biosurfaktan jenis rhamnolipid yang berasal Pseudomonas aeruginosa dapat digunakan di berbagai industri seperti produk kimia, bahan tambahan untuk pengelolaan lingkungan, dan agen biologis. Pada industri kosmetik dan perawatan kesehatan menggunakan sejumlah besar biosurfaktan untuk berbagai macam produk termasuk: penolak serangga, antasida, jerawat, produk anti-ketombe, caitan lensa kontak, pewarna dan produk perawatan rambut, deodoran, produk perawatan kuku, lipstik, eyeshadow, maskara, pasta gigi, pembersih gigi tiruan, antipespiran, produk bayi, produk perawatan kaki, antiseptik, produk cukur dan obat menghilangkan rambut, dan pelembab [6]. Selain itu, biosurfaktan jenis lainnya seperti surfactin yang berasal dari Bacillus subtilis, dapat diaplikasikan untuk antivirus, antibiotik, antimikroba dan antifungi $[7,8]$.
Bakteri keratinolitik merupakan bakteri yang mampu mendegradasi protein keratin. Keratin memiliki struktur berserat yang merupakan komponen utama dari bulu ayam, kuku, dan tanduk. Isolat bakteri keratinolitik diketahui memiliki potensi dalam aplikasi bioteknologi untuk proses yang melibatkan hidrolisis keratin, agen dehairing pada industri penyamakan kulit, pupuk nitrogen, industri kosmetik dan deterjen. Jenis bakteri keratinolitik seperti Bacillus subtilis PF1 diketahui mampu memproduksi protease keratinolitik [9].

Skrining biosurfaktan dapat dilakukan dengan metode uji oil displacement dan metode emulsifikasi. Metode oil displacement digunakan untuk memperoleh diameter zona perpindahan minyak yang dicatat sebagai nilai oil displacement area (ODA), sedangkan metode emulsifikasi digunakan untuk mendapatkan lapisan emulsi pada larutan yang dicatat sebagai nilai indeks emulsifikasi (IE24) [10]. Penggunaan kedua teknik ini dapat digunakan untuk menyeleksi bakteri potensial penghasil biosurfaktan (Youssef dkk, 2004) karena mudah dan praktis untuk dilakukan, tidak memerlukan peralatan khusus dan hanya membutuhkan volume sampel yang sedikit (Plaza dkk, 2006) [11.12]. Penelitian ini bertujuan untuk menguji potensi bakteri keratinolitik sebagai penghasil biosurfaktan dengan menggunakan metode oil displacement dan emulsifikasi. Diharapkan hasil penelitian ini dapat menjadi referensi tambahan bagi peneliti selanjutnya untuk dapat menjadikan bakteri keratinolitik menjadi salah satu bakteri yang dapat menghasilkan biosurfaktan.

\section{Metode}

\subsection{Isolat Bakteri}

Bakteri yang digunakan dalam penelitian ini adalah dua isolat bakteri keratinolitik yaitu PK09 dan LU04 yang berasal dari koleksi Laboratorium Mikrobiologi, Departemen Biologi FMIPA USU Medan, Indonesia. Stok kultur kedua isolat diremajakan pada media nutrient agar (NA), diinkubasi pada suhu $37^{\circ} \mathrm{C}$ selama 24 jam.

\subsection{Produksi Biosurfaktan}

Kedua isolat bakteri yang telah disubkultur kemudian dibuat suspensi bakteri dengan $\mathrm{OD}_{600}=0,5$. Suspensi bakteri sebanyak $5 \mathrm{~mL}$ diinokulasi ke dalam $100 \mathrm{~mL}$ media produksi yang telah dimodifikasi berupa mineral cair untuk pertumbuhan yang telah ditambahkan dengan minyak zaitun dengan komposisi: pepton $0,2 \% ; \mathrm{NH}_{4} \mathrm{H}_{2} \mathrm{PO}_{4} 0,1 \% ; \mathrm{NaCl}$ $0,25 \% ; \mathrm{MgSO}_{4} .7 \mathrm{H}_{2} \mathrm{O} 0,04 \% ; \mathrm{CaCl}_{2} \cdot 2 \mathrm{H}_{2} \mathrm{O} 0,04 \%$ (b/v); minyak zaitun 2,0\% (v/v), dan air aquades steril [13]. Media produksi yang sudah dikultur oleh suspensi bakteri kemudian diinkubasi pada suhu $37^{\circ} \mathrm{C}$ 
dalam inkubator shaker Vision Scientific Co.Ltd. kecepatan $160 \mathrm{rpm}$ selama 8 hari. Pertumbuhan sel dan aktivitas produksi biosurfaktan diamati setiap hari.

\subsection{Pemanenan Produksi Biosurfaktan}

Kultur bakteri dalam media produksi dipanen setiap hari dan dilakukan pengujian aktivitas biosurfaktan. Pemanenan dimulai dari hari pertama hingga hari kedelapan. Sampel kultur bakteri yang telah dipanen kemudian disentrifugasi pada mesin sentrifus Thermo Scientific dengan kecepatan 13.000 rpm selama 10 menit pada suhu $4{ }^{\circ} \mathrm{C}$ sehingga diperoleh supernatan yang mengandung biosurfaktan bebas sel.

\subsection{Uji Oil Displacement}

Pengujian aktivitas biosurfaktan menggunakan teknik oil displacement dilakukan dengan cara mengisi cawan petri dengan aquades steril sebanyak $50 \mathrm{~mL}$, kemudian di atas permukaan aquades ditambahkan minyak zaitun secara perlahan-lahan sebanyak $100 \mu \mathrm{L}$. Pengujian oil displacement dilakukan dengan cara cairan supernatan biosurfaktan bebas sel sebanyak $50 \mu \mathrm{L}$ kemudian dituang ke atas permukaan minyak zaitun. Terbentuknya zona jernih pada permukaan minyak menunjukkan positif adanya aktivitas biosurfaktan. Zona jernih ini disebut oil displacement area (ODA). Besarnya nilai ODA dihitung berdasarkan besarnya diameter zona jernih yang terbentuk pada permukaan minyak zaitun. Kontrol negatif menggunakan air aquades steril (tanpa biosurfaktan). Diameter zona jernih pada permukaan minyak diukur dengan tiga replikasi untuk masingmasing isolat [14].

\subsection{Pengukuran Indeks Emulsifikasi (IE24)}

Pengujian aktivitas biosurfaktan selanjutnya adalah mengukur indeks emulsifikasi (IE24) dengan cara melakukan teknik emulsifikasi dari aktivitas biosurfaktan. Pengujian emulsifikasi biosurfaktan dilakukan dengan cara mengisi tabung reaksi yang berukuran kecil dengan minyak zaitun sebanyak $2 \mathrm{~mL}$, kemudian ditambahkan cairan supernatan biosurfaktan bebas sel di atas minyak zaitun sebanyak $2 \mathrm{~mL}$ (perbandingan 1:1). Selanjutnya tabung reaksi divortex dengan alat vortex Vision Scientific Co.Ltd. secara maksimal selama 2 menit hingga teremulsi atau tercampur sempurna, dan kemudian disimpan pada suhu ruangan selama 24 jam. Setelah 24 jam dilakukan pengamatan emulsi antara minyak zaitun dengan cairan supernatan biosurfaktan. Jika masih terbentuk emulsi antara minyak zaitun dan cairan supernatan biosurfaktan maka dapat dinyatakan positif supernatan tersebut mengandung biosurfaktan. Nilai indeks emulsifikasi ditentukan sebagai persentase tinggi lapisan emulsi dibagi dengan tinggi total larutan. Indeks Emulsifikasi (IE24) dihitung dengan persamaan $=($ Tinggi Lapisan Emulsi $\mathrm{x} 100 /$ Total Tinggi Larutan) [15].

\section{Hasil dan Pembahasan}

\subsection{Uji Oil Displacement}

Pengujian aktivitas biosurfaktan dengan teknik uji oil displacement dilakukan dengan melihat perpindahan minyak dan menghasilkan zona perpindahan yang terbentuk dipermukaan minyak, seperti yang ditunjukkan pada Gambar 1. Terbentuknya zona jernih menujukkan adanya kandungan biosurfaktan pada supernatan. Nilai ODA pada aktivitas biosurfaktan merupakan salah satu kriteria untuk mendukung pemilihan produsen biosurfaktan yang potensial dari mirkoba [1].

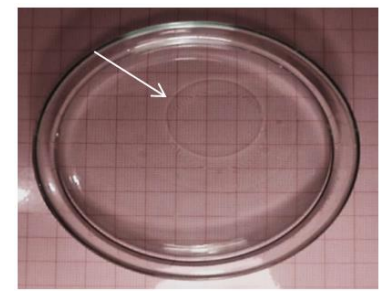

Gambar 1. Pengujian aktivitas biosurfaktan dengan teknik oil displacement. Tanda panah menujukkan terbentuknya zona jernih (ODA) pada permukaan lapisan minyak.

Hasil penelitian ini menunjukkan bahwa uji oil displacement (perpindahan minyak) positif dengan terbentuknya zona jernih disekitar lapisan minyak. Terbentuknya zona jernih minyak berbanding lurus dengan adanya senyawa aktif permukaan biosurfaktan yang terdapat di dalam larutan [14]. Nilai hasil pengujian oil displacement dari kedua isolat dapat dilihat pada Tabel 1. dengan nilai zona jernih tertinggi masing-masing 15,0 mm untuk isolat PK09 dan 38,0 $\mathrm{mm}$ untuk isolat LU04.

Tabel. 1 Nilai ODA isolat bakteri PK09 dan LU04

\begin{tabular}{ccc}
\hline Hari ke- & Isolat PK09 & Isolat LU04 \\
\hline 0 & 0 & 0 \\
1 & 6,5 & 10,5 \\
2 & 7,5 & 26,0 \\
3 & 7,8 & 32,0 \\
4 & 8,0 & 38,0 \\
5 & 8,5 & 34,2 \\
6 & 9,0 & 32,5 \\
7 & 10,0 & 30,5 \\
8 & 15,0 & 29,0 \\
\hline
\end{tabular}

Ket: ODA = Oil Displacement Area $(\mathrm{mm})$ 


\subsection{Pengukuran Indeks Emulsifikasi (IE24)}

Pengujian aktivitas biosurfaktan menggunakan metode emulsifikasi dilakukan dengan mengukur indeks emulsifikasi (IE24) dari terbentuknya emulsi pada larutan. Nilai emulsifikasi diperoleh dari persentase tinggi lapisan emulsi dibagi dengan tinggi total larutan seperti yang ditunjukkan pada Gambar 2. Terbentuknya emulsi menujukkan adanya kandungan biosurfaktan pada supernatan. Nilai indeks emulsifikasi pada aktivitas biosurfaktan merupakan salah satu kriteria yang dilakukan untuk mendukung pemilihan produsen biosurfaktan yang potensial dari mirkoba [11].

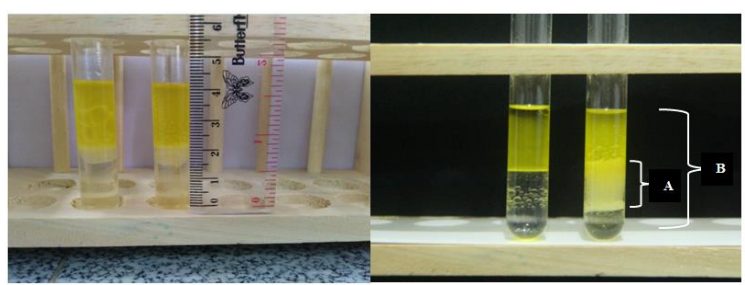

Gambar 2. Pengujian aktivitas biosurfaktan dengan teknik emulsifikasi. Adanya aktivitas produksi biosurfaktan ditunjukkan dengan terbentuknya lapisan emulsi.

Ket: $\quad \mathrm{A}=$ tinggi emulsi

$\mathrm{B}=$ tinggi larutan

Hasil penelitian ini menunjukkan bahwa dari uji emulsifikasi yang positif ditandai dengan terbentuknya lapisan emulsi pada larutan. Terbentuknya lapisan emulsi berbanding lurus dengan adanya senyawa aktif permukaan biosurfaktan di dalam larutan. Nilai indeks emulsifikasi (IE24) dari kedua isolat yang diuji memberikan hasil positif (tabel 2). Nilai indeks emulsifikasi tertinggi masing-masing 15\% untuk isolat PK09 dan 20\% untuk isolat LU04.

Tabel. 2 Nilai indeks emulsifikasi (IE24) isolat bakteri PK09 dan LU04

\begin{tabular}{ccc}
\hline Hari ke- & Isolat PK09 & Isolat LU04 \\
\hline 0 & 0 & 0 \\
1 & 2,0 & 4,0 \\
2 & 4,0 & 8,0 \\
3 & 6,0 & 14,0 \\
4 & 6,0 & 20,0 \\
5 & 8,0 & 19,0 \\
6 & 10,0 & 18,0 \\
7 & 10,0 & 17,0 \\
8 & 15,0 & 17,0 \\
\hline
\end{tabular}

Ket: IE24 = Indeks Emulsifikasi (\%)

Nilai indeks emulsifkasi merupakan metode sederhana yang dapat digunakan untuk menyeleksi mikroba penghasil biosurfaktan. Jika supernatan bebas sel mampu mengemulsi hidrokarbon yang ada pada larutan maka dapat dipastikan mengandung biosurfaktan. Seperti penelitian yang pernah dilakukan sebelumnya bahwa dengan menggunakan teknik emulsifikasi diperoleh nilai nilai indeks emulsifikasi sebesar $87 \%$ pada Bacillus dan $15 \%$ pada E. coli yang menunjukkan bahwa adanya aktivitas produksi biosurfaktan [16].

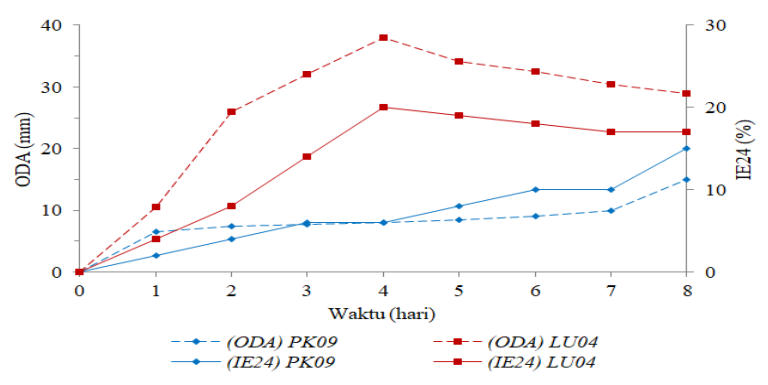

Gambar 3. Grafik nilai oil displacement area (ODA) dan indeks emulsifikasi (IE24) dari isolat bakteri PK09 dan LU04

Gambar 3. menujukkan grafik perolehan nilai ODA dan IE24 pada kedua isolat bakteri. Grafik nilai ODA relatif sejalan untuk kedua isolat. Demikian juga dengan nilai indeks emulsifikasi pada kedua isolat bakteri. Hal ini menunjukkan bahwa pengujian oil displacement dan emulsifikasi dapat dijadikan pilihan untuk metode dalam mendeteksi produksi biosurfaktan pada bakteri. Pada studi lain juga digunakan metode pengujian oil displacement dan emulsifikasi seperti perolehan zona jernih sebesar 24 $\mathrm{mm}$ dan indeks emulsifikasi sebesar $76 \%$ untuk Bacillus subtilis A1. Adanya aktivitas dari perpindahan minyak dan emulsifikasi menunjukkan adanya keberadaan biosurfaktan dalam supernatan bebas sel [3].

Mikroorganisme menghasilkan senyawa biosurfaktan untuk mengemulsi minyak atau hidrokarbon lainnya yang sulit teremulsi. Mikroorganisme mensintesis biosurfaktan untuk dapat mengemulsi senyawa yang tidak larut dalam air [17]. Biosurfaktan dihasilkan oleh reaksi metabolisme sekunder dengan fungsi sel adhesi dan motilitas, diferensiasi dan aksesibilitas ke substrat dan molekul penyimpanan karbon dan energi [18].

Adanya bagian polar dan non-polar dari molekul yang terbentuk pada biosurfaktan merupakan sifat surfaktan yang dapat disintesis dari metabolisme lipid dan karbohidrat [17]. Mono dan digliserida adalah biosurfaktan yang dapat dibentuk oleh aktivitas lipase yang menghidrolisis trigliserida. Oleh karena itu komponen yang memiliki bagian polar dan non-polar yang sama menunjukkan bahwa biosurfaktan memiliki sifat aktif permukaan (surface active) [19]. 
Aktivitas biosurfaktan yang terjadi pada minyak di dalam air, dimana bagian molekul surfaktan nonpolar yang hidrofobik berikatan dengan minyak dan bagian polar yang hidrofilik berikatan dengan air [20]. Dengan Adanya kedua gugus hidrofilik dan hidrofobik membuat biosurfaktan menjadi dapat berinteraksi dengan berbagai jenis hidrokarbon. Bagian lipid hidrofobik membentuk ekor (non-polar tail) pada molekul biosurfaktan hampir mirip pada semua jenis mikroba. Bagian polar hidrofilik (polar head) pada molekul biosurfaktan digambarkan seperti kepala yang merupakan kelompok beragam yang sebagian besar terdiri dari berbagai glycan, protein, dan zat polimer lainnya dari mikroba.

\section{Kesimpulan}

Tujuan penelitian ini adalah untuk mencari sumber penghasil biosurfaktan dari isolat bakteri keratinolitik menggunakan teknik metode oil displacement dan emulsifikasi. Berdasarkan hasil penelitian ini dapat disimpulkan bahwa kedua isolat bakteri keratinolitik yang diuji memiliki aktivitas biosurfaktan, dan dapat dijadikan sebagai sumber referensi bahwa bakteri keratinolitik dapat menghasilkan senyawa biosurfaktan.

\section{Ucapan Terima Kasih}

Ucapan terima kasih kepada Universitas Muslim Nusantara (UMN) Al-Washliyah atas dukungan dan bantuannya dalam pelaksanaan penelitian ini.

\section{Daftar Pustaka}

[1] Shoeb, E., Akhlaq, F., Badar, U., Akhter, J., Imtiaz, S. 2013. Classification and industrial applications of biosurfactants. Academic Research International 4: 243-252.

[2] Tabatabaee, A., Assadi, M. M., Noohi, A. A., Sajadian, V. A. 2005. Isolation of Biosurfactant Producing Bacteria from Oil Reservoirs. Iranian J ENV Health Sci Eng, 2(1): 6-12.

[3] Parthipan, P., Preetham, E., Machuca, L. L., Rahman, P. K. S. M., Murugan, K., Rajasekar, A. 2017. Biosurfactant and Degradative Enzymes Mediated Crude Oil Degradation by Bacterium Bacillus subtilis A1. Front. Microbiol, 8: 193. Doi: 10.3389/fmicb.2017.00193.

[4] Ibrahim, M. L., Ijah, U. J. J., Manga, S. B., Bilbis, L. S., Umar, S. 2013. Production and Partial Characterization of Biosurfactant Produced by Crude Oil Degrading Bacteria. Int. Biodeterior. Biodegrad, 81: 28-34.

[5] El-Sheshtawy, H. S., Doheim, M. M. 2014. Selection of Pseudomonas aeruginosa for Biosurfactant Production and Studies of Its
Antimicrobial Activity. Egyptian Journal of Petroleum, 23: 1-6.

[6] Maier, R., Soberon-Chavez, G. 2000. Pseudomonas aeruginosa rhamnolipids: biosynthesis and potential applications. Appl Microbiol Biotechnol; 54: 625-33.

[7] Vollenbroich, D., Ozel, M., Vater, J. et al. 1997. Mechanism of inactivation of enveloped viruses by the biosurfactant surfactin from Bacillus subtilis. Biologicals; 25: 289-97.

[8] Vollenbroich, D., Pauli, G., Ozel, M. et al. 1997. Antimycoplasma properties and applications in cell culture of surfactin, a lipopeptide antibiotic from Bacillus subtilis. Appl Environ Microbiol; 63: 44-9.

[9] Bhange, K., Chaturvedi, V., Bhatt, R. 2016. Simultaneous production of detergent stable keratinolytic protease, amylase and biosurfactant by Bacillus subtilis PF1 using agro industrial waste. Biotechnology Reports, 10: 94-104.

[10] Shoeb, E., Ahmed, N., Akhter, J., Badar, U., Siddiqui, K., Ansari, F. A., Waqar, M., Imtiaz, S., Akhtar, N., Shaikh, Q. A., Baig, R., Butt, S., Khan, S., Khan, S., Hussain, S., Ahmed, B., Ansari, M. A. 2015. Screening and Characterization of Biosurfactant-Producing Bacteria Isolated from The Arabian Sea Coast of Karachi. Turk J Biol, 39: 210-216.

[11] Youssef, N. H., Duncan, K. E., Nagle, D. P., Savage, K. N., Knapp, R. M., McInerney, M. J. 2004. Comparison of Methods to Detect Biosurfactant Production by Diverse Microorganisms. J Microbiol Methods, 56: 339347.

[12] Plaza, G., Zjawiony, I., Banat, I. 2006. Use of Different Methods for Detection of Thermophilic Biosurfactant-Producing Bacteria from Hydrocarbon-Contaminated Bioremediated Soils. J Petro Science Eng, 50: 71-77.

[13] Saravanan, V. and Vijayakumar, S. 2012. Isolation and screening of biosurfactant producing microorganisms from oil contaminated soil. J. Acad. Indus. Res. Vol. 1(5).

[14] Morikawa, M., Diado, H., Takao, T., Murata, S., Shimonishi, Y., Imanaka, T. 1993. A new lipopeptide biosurfactant produced by Arthrobacter sp. strain MIS38. J Bacteriol 175: 6459-6466.

[15] Asfora Sarubbo, L., Moura de Luna, J., de Campos-Takaki, G. M. 2006. Production and stability studies of the bioemulsifier obtained from a new strain of Candida glabrata UCP 1002. Electron J Biotechnol, 9: 4.

[16] Nayarisseri, A., Singh, P., and Singh, S. K. 2018. Screening, Isolation and Characterization of 
Biosurfactant Producing Bacillus subtilis strain ANSKLAB03.Bioinformation, 14(6):304-314.

[17] Desai, J.D. and Banat, I. M. 1997. Microbial Production of Surfactant and Commercial Potential. J. Microbiology and Molecular Review, 61: 47-64.

[18] Van Hamme, J. D., Singh, A. and Ward, O. P. 2006. Physiological aspects - part 1 in a series of papers devoted to surfactants in microbiology and biotechnology. Biotechnol. Adv., 24:604-620.

[19] Colla, L. M., Rizzardi, J., Pinto, M. H., Reinehr, C. O., Bertolin, T. E. and Costa, J. A. V. 2010. Simultaneous Production of Lipases and Biosurfactants by Submerged and Solid-state Bioprocesses. Bioresource Technology, 101:8308-8314.

[20] Santos, D. K. F., Rufino, R. D., Luna, J. M., Santos, V. A., Sarubbo, L. A. 2016. Biosurfactants: Multifunctional Biomolecules of the 21st Century. Int. J. Mol. Sci, 17: 401. 